\title{
COMMUNICATION AS SACRED AND MISSIONARY ACT. A CONTEMPORARY ETHICAL NECESSITY
}

\author{
Prof. Ph.D. Florea ŞTEFAN, \\ Doctoral School of Theology „1 Decembrie 1918” University of Alba Iulia, \\ Faculty of Theology and Sciences of Education, Valahia University of Târgovişte, \\ ROMANIA \\ Email:pr_floreastefan@yahoo.com
}

\begin{abstract}
This study deepens the sacramental meaning of the 'word' as a means of communion and perfection for man. The incarnation of the Word of God and Christianity, by and large, led to the change of our paradigm of civilization. The Church uses today the word to promote its pastoral mission, as fundamental means of inculturation and as tool for deepening human communion and solidarity. The word has a sacramental perspective and always implies dignity and responsibility. The Christian civilization is one founded on the word, which is the reason it best expresses the dignity and the divine greatness of the word. The Church cannot stand apart in front of the social effects of technological progress of media, as it strongly affects people's lives, for better or worse, as used, with or without discernment.
\end{abstract}

Keywords: word; communication; communion; sacred; Church; language;

\section{INTRODUCTION}

Language is a peculiar human gift, awarded by the Creator, which sets him apart from all other living beings. The word is specific to man; it is a main instrument of thinking, relationships, communication and communion with his neighbor. It is proper for man to relate through language, to create bridges with his neighbor. God Himself communicates with man through the word, and from this point of view, the most eloquent is the event of the Son of God's Incarnation. The Word became flash (John 1,14), which shows that God has sanctified the language in the highest degree; He made his language out of our language or rather our language is a reflection of His language. ${ }^{1}$

From this perspective language is a privilege, but also a sacramental act. Once we pray and communicate with God, the divine grace descends through the Holy Sacraments and hierurgy, sacramental works that involve the word.

The word is an invocation. It is the extension or externalization of the thought of our heart; it is the externalization or projection of our own way of being and relating. Through word we emanate a form of our personality, an imprint of what we are and what we want to communicate.

Because it is inherent to man, as an ontological given, but also a form of communication used by God Himself, the word is a sacred act, because its purpose is to

\footnotetext{
${ }^{1}$ Virgil NemoIAnU, Jocurile divinităţii. Gândire, libertate şi religie la sfârşit de mileniu (The games of Divinity. Thought, Freedom and Religion at the end of the millennium), Polirom, Iaşi, 2000, p. 38.
} 
support our salvation, the relationship with God and our neighbors, in our specific form of communication.

Language participates at our salvation, contributes to it or to our decay. It pierces, as St. Apostle Paul says, even to the dividing asunder of soul and spirit or of body and soul (Hebrews 4:12) and we all know that a foolish spoken word can destroy a life-long relationship. It is true that few people have the delicacy and wisdom to truly understand what the real meaning of the word is and what immense power it has in it, so as to use this blessed and human instrument in the most appropriate way.

The Philokalia includes an immense delicacy and tenderness of the relationship in the vision of the Desert Fathers who, by purifying themselves, rediscovered the true power and the authentic meaning of the word.

The word is a true stairway to heaven or hell, depending on the way we use it; it is also the bearer of the good within us or manifestation of the vice and sin that gnaws us. ${ }^{2}$

Language is one of the most important aspects of anthropology and soteriology because it is the one that can gain or lose salvation depending on its proper or inadequate use.

From its very beginning, Christianity claimed itself as a religion of the word, of the book, which is the reason at the foundation of the Christian event stays the Holy Scripture, a collection of words inspired by the Holy Spirit, and the Holy Tradition, an inspired collection as well, both being aspects of the living and inspired working word, so dynamic in our history.

\section{COMMUNICATION AS SACRED AND MISSIONARY ACT}

Revelation in the biblical sense is a mysterious process, a direct communication from God to man for his salvation. It is the word of God inspired by the Holy Spirit. In the New Testament frameworks, revelation is identified with the gracious iconography by which God is fully and plenary revealed in Jesus Christ, the Incarnate Son of God. "Revelation also means the revealing of hidden mysteries, communicating some teachings about God, but it is also the good news (euvangelion), the gospel of salvation and the grace of salvation in Christ. In this sense, Christ is the Revelator and the divine revelation itself, our Savior and our salvation"3.

The ontological arguments that support the importance of communication and communion for human-specific conscious actions in the process of perfection can be synthesized from a logical, scriptural and patristic point of view as follows:

a) God is Person - and the person assumes loving communion, creating the man out of love, He wants to reveal Himself to man.

b) Man, created as a person, is capable of communion. Being an image of God, man is endowed with reason, so that he can know God.

c) After falling into sin, the image of God in man was not completely destroyed, but only a deterioration (darkening) of the image was produced. Man remains capable of communion with God after falling.

d) The world is created by God as a gift for man; it is a means of dialogue between God and man, a dialogue in which man is called to continually discover God in creation.

\footnotetext{
2 ***, Etica in Internet. Biserica şi Internetul (Ethics in the Internet. The Church and the Internet), Consiliul Pontifical pentru Comunicații Sociale Ercis, Iași, 2002, p. 12.

${ }^{3}$ Pr. Prof. Ion BRIA, „Despre revelaţia dumnezeiască” (On the divine revelation), in: Glasul Bisericii, Year XXII (1964), no. 3-4, p.184.
} 
It is worth noting that the emergence and spread of Christianity is the one that gave dignity to the word and operated the transition from oral culture to the written one, because the Word alone was embodied and gave us the opportunity to materialize what we used to transmit through lively voice. The Incarnate Word made our human word tangible, gave it dignity and charged it with great responsibility, for our own salvation and for our neighbor's likewise. Thus, in the early epoch of the Church the apostolic Letters appear, which are copied by as many Christian communities, followed then by the gospels and in this manner the word is becoming an important part of the worship of God, a fundamental part of our culture that is gaining another development and other valences.

Our culture is word-based and relies on the Incarnation of the Son of God, and the European civilization, with its great peaks is nothing but the fruit of Christianity exclusively, while the other contributions, i.e. Judaic and Greco-Roman are only marginally formal.

The word of God gets united with the word of man and builds up our Christian and European civilization and culture, which is thereby a revealed culture that has supernatural meaning and goals, but more than that it gives immense dignity to the word.

Between dignity and responsibility, between the word of God and the word of man, behold! - these are the boundaries of the Christian civilization of the word, mirrored in the Holy Tradition and in the Holy Scripture.

The word is the skeleton of our European and Romanian culture and civilization as well, and this comes out of everything that has been created, even from word as image, icon and painting though some argue that image have dethroned the word ${ }^{4}$.

Europe is a civilization of the word, founded on Christianity which in its turn is built on the Incarnation of God's Son, such that is not randomly that our culture is a drag-net culture, interwoven through words.

The immense dignity of the word is given by the fact that God is the one who utters: Let there be light!, and all the other utterances, which show that man, imitating God in the act of the word, goes confidently on the path of salvation, and between the word of man and the word of the Lord our salvation is to be written.

The sacredness of the word is an inner reality of it because it is God's creation and a gift to us, given for a particular purpose and therefore to use it inappropriately means to dishonor the Giver, to offend the one who expects us to use the word as an instrument of communion and perfection, and not as a means of separation and discord, isolation and evil.

Communication is a natural human act, ontologically necessary and practically fundamental, which represents not only the reaction to the need of the immediate, but especially a proper way of sharing something from one's own ontology. "Man is a person, an image of God, because there is a possibility of an answer to the call to love of God. Through his psychosomatic functions, man administers this possibility, responds positively or negatively to the call of God, leads his existence either to life, which means relationship, or to death which signifies separation from God." ${ }^{5}$

The act of communication is deeply a religious one. God the Son Incarnate is also called Logos, that is reason, but the term also means communication; also within the Holy Trinity, we are talking about communication and relational fellowship ${ }^{6}$. In other words,

\footnotetext{
${ }^{4}$ Giovanni SARTORI, Homo videns. Imbecilizarea prin televiziune şi post-gândirea (Homo videns. Idiotizing through television and post-reasoning), transl. into Romanian by Mihai Elin, București, Humanitas, 2005, p. 11.

${ }^{5}$ Christos Yannaras, Abecedar al credinţei (Elements of Faith: An Introduction to Orthodox Theology), transl. in Romanian by Rev. Dr. Constantin Coman, Bizantină, Bucuresti, 1996, p. 85

${ }^{6}$ Le Culte de l'Internet. Une menace pour le lien social?, La Découverte, Paris, 1999, p. 104.
} 
between communication and communion there is a close, strong and even inseparable connection. ${ }^{7}$

Man is a social being, that is, he has the ability to communicate, the openness and the vocation to communicate that is inscribed in his ontological datum, in the image of God within him. In fact, this is also the main argument of the possibility and necessity of our communication with God. We, as persons naturally have the ability to communicate inscribed in the divine depth within us.

From this perspective, the act of communication is a sacred one, because it pertains to the will of God, who created us as rational beings, once He is the Supreme Reason. To communicate is therefore the most natural human act, and, at the same time, it is the act that sets us in relation with the Creator.

By his creative status as a dialogue partner of God, man is a dynamic being; his whole life presents as a continuous tension that invokes the grace of the life-giving Holy Spirit. Thus the Christian life is characterized by incorporation and living in Christ towards the

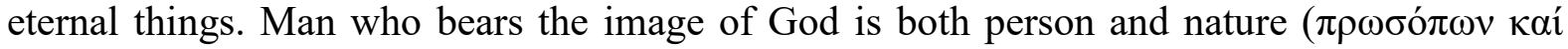
$\pi \chi \eta ́ \sigma \varepsilon$ ), or more precisely, the person who assumes nature (being) and reveals it. Ontologically man is called to knowledge.

Thus, the human nature is fundamentally crossed by the mystery of love as an impulse that pushes people from within to a natural communion. The eternal value of the human person, the uniqueness of his being realized through the unity of the contrasts that man represents as body and soul, discovers that the person is not brought into the world by God in isolation, as an abstract uniform realization, separate from nature, from being.

The person presents himself in the complex context of the bonds of love and care manifested to himself and to other persons distinct from him, but who share the same common nature, in which the divine presence dwells in secret. Thus, it is reflected in humanity, through the creation of man in the image, the existential way of being like God, achieved through the dialogue of love between the persons of the Holy Trinity and the human persons, without mixing and without confusion, by the grace that reconcile those created with the uncreated ones.

The orthodox teaching does not conceive of human nature without grace, because grace as uncreated divine energy, which springs from the divine being, understood as the common energy of the three hypostases, is poured out personally through the Holy Spirit, through the risen and exalted humanity of Christ, in the sacramental framework of the Church through the Holy Sacraments, for the purpose of our salvation and sanctification. This process, seen as a continuous Pentecost, is actually the communion with Christ in the Holy Spirit, who exalts humanity to its true way of existence. The man's haric aspiration to God can be understood by the fact that through the life breath of the Holy Spirit appears into man a 'you' of God, who is the image of God-You. God creates from nothing a dialogue partner in a biological organism through the spiritual blowing of grace, which produces an ontological spiritual breath that gets updated in the interpersonal conscious relationship.

The human subject participates in the divine life. Man has, through creation, the opportunity to transform into grace and to be like God: "In this sense, the orthodox anthropology is the ontology of deification ..." 8

\footnotetext{
${ }^{7}$ J.-Cl. MONOD, Écrire à l'heure du tout message, Flammarion, Paris, 2015, p. 66

${ }^{8}$ Paul Evdochimov, Ortodoxia (The Orthodoxy), transl. into Romanian by Irineu Ioan Popa, Institutul Biblic si de Misiune al Bisericii Ortodoxe Române, Bucureşti 1996, p. 103
} 


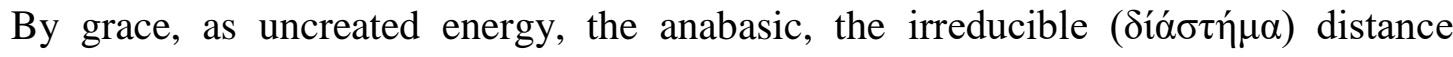
between the image and the divine archetype can be crossed by the absolute powerlessness of any mixture: "what has been done after the image means that it resembles the pattern... But it is quite different than its model if we consider the characteristics of its nature. For if the human mind were entirely God, it would no longer be his image, and it is precisely in the characteristics of the unborn nature that the image is revealed; in these properties the built nature shows the model...",

We could, therefore, say that man is a communicative and of relationship being, open to his fellows and to God, and the act of communicating is also a means that contributes to his salvation.

Communication is related to anthropology and soteriology, but also to eschatology, because during the process from image to likeness, which has an always renewing character and without end, communication plays an important role.

From the moral point of view, the correct communication is the one which means that man relates to his neighbor without getting caught in the slavery of sin, and this is the desire. But we know it is not so, and yet man is subject to sin, and communication is also altered by sin. The work of the redemption of the God the Son Incarnate included this aspect of communication more precisely, and Jesus the Lord gave the real depth of communication, making it a stairway to heaven, a gate of renewal and a way of transfiguration.

That is why the Holy Sacraments and hierurgy, through which the grace of God enters our lives, have an aspect that pertains to communication, to the sacredness of communication, and through volitional effort, we transform the sacredness of communication into the sanctity of communication, that is, from ontological given to the renewal, by the Divine-human synergism.

The Church as the mysterious Body of Christ contains within the Spirit of truth (John 15:26, Romans 8:26), which gives her the ability to know the revealed truth and to keep it. The Holy Fathers testify that the Church is based on the same faith, on the community of faith preached by the special hierarchy that comes from Christ through the apostolic succession. To communicate, therefore, has a doctrinal aspect, which belongs to the image of God, a moral one concerning its truth and non-alteration, and a soteriological one concerning our perfection or salvation, in addition to the eschatological one, which concerns the participation in grace in the eternal life.

Morality is not a notion that is shaped by the "stories" crossed by humanity. Morality is a stable, integral, resonant concept, which does not subordinate to the times but, on the contrary, subordinates them. This cannot acquire shades, because it is not a trivial thing, a style of clothing, architecture, not even a philosophical current, which some can fashion unconditionally.

The novelty of the moral perspective of the Church refers both to the holistic integration of communication, and as a sacred act, in the process of deepening communion and social cohesion, but also to specifying and developing certain ethical principles and creating an integrative vision of the act of communication, as a social, relational and sacred act. Certainly, the reality of the transcendental, religious life is the revealed foundation in which to communicate means the natural haric existence specific to human.

\footnotetext{
${ }^{9}$ St. Gregory of Nyssa, Despre suflet şi inviere (About the soul and resurrection), in: PSB, vol. 30, Institutul Biblic si de Misiune al Bisericii Ortodoxe Române, Bucureşti 1998, pp. 359 - 360.
} 
From the beginning, through what we started to call 'process of inculturation', the Church has used the word as a means of promoting the Gospel, as a tool for purifying the Greek-Roman culture, for spiritualizing and transfiguration of, it as well. Thus, the Church took the forms of expressing the Greco-Roman culture to which it gave new Christian content, i.e. it "baptized" them, in such a way as to be easy to penetrate into the ancient mentality, but to carry not pagan but Christian ideas, not paganism but Christianity.

On the same principle, in each epoch, the Church took over something from the culture of that time, using the word as a means of encounter and transfiguration.

Coming to the present times, the Church looked, at first, to the media with some fear, perhaps because of the fact that for so many centuries it has carried out its pastoralmissionary activity, using the classical means of preaching; however, we must not rely too much on this ecclesial conservatism, especially if we remember that the Church has always taken the newest means of communication in order to promote the Gospel, from papyrus and parchment, up to the use of printing press or radio.

Today, the use of the Internet, 'the new evangelization forum'10, or 'the new Areopagus', or the use of television, mobile communications or of the presentations on electronic, magnetic or purely informational media, does not represent - we firmly believe a danger in terms of superficiality in the presentation of the redemptive message.

Of course, the case of excessive use of such means, without a serious discernment and without a clear and intelligent strategy can create problems of understanding, reception or deepening.

The presence of the Church in the public space through the media is an urgent and permanent duty, because it is a charitable gesture to proclaim the word of God as effectively as possible. ${ }^{11}$

Jesus and the Apostles used all the modern means of their time to present their message, so that no means of communication should be denied or removed from the strategy of preaching the divine word.

Promoting light, justice, joy, bringing hope and comfort is always, not only permitted, but compulsory for any Christian.

Those who raise the issue that the Church is a private business (and that from the Enlightenment epoch onwards) and is not fair to manifest publicly or that it would aggress the free-thinking person with its message, do so out of false and dangerous political correctness, because, as long as the Church promotes its values, it cannot be against the man and his deepest interests.

The Church must value the use of all means of social communication that use or have the word as a vehicle, because it must preach the word of salvation to all, and impregnate with the divine seal of the transforming love of God everyone and everything ${ }^{12}$. To the extent that the postmodern man seeks immediate salvation, he must increasingly resort to modern, institutionalized procedures, which society so willingly offers today.

\footnotetext{
${ }^{10}$ IOAN PAUL al II-lea (JOHN PAUL the second), Internetul: un nou forum pentru proclamarea Evangheliei. Mesaj cu ocazia celei de a XXXVI-a Zi Mondială a Comunicaţiilor Sociale (The Internet: a new forum for proclaiming the Gospel. Message on the occasion of the XXXVI-th World Social Communications Day, 12 May 2002, Presa Bună, Iaşi, 2002, p. 4.

${ }^{11}$ BENEDICT XVI, Mesajul pentru a 45-a Zi Mondială a Comunicațiilor Sociale (The message for the 45th World Day of Social Communications), 2011.

${ }^{12}$ V.: https://ziarullumina.ro/repere-si-idei/internetul-intre-comunicare-si-izolare-15816.html
} 
The mission in the urban milieu is one of the urgent problems of the Church in the contemporary society. Due to the policies of the communist regime, the country's major cities experienced impressive population growth, while the Church was hindered from constructing places of worship. To all this, we can add the religious formalism that many of the believers grown up in the communist period exhibit, and the carelessness of those shaped in the spirit of postmodern thought, who participate from a social impulse at the Church' life and activity. For the Christian world, the acceptance of the responsibility to get involved in the process of straightening the different postmodern social mindsets that must conform to the essence of the way of thinking in Christ is already a great challenge.

The role of Christian moral education is essential to the health of contemporary society. "The first step, fundamental in order to achieve this 'cultural tower', consists in the formation of the moral consciousness regarding the immeasurable and immaterial value of each human life. It is very important for you to rediscover the intact connection between life and freedom and to discover the constitutive link that unites freedom with truth. ${ }^{13 "}$

Any religious community should be defined by spiritual health. Because postmodern society gives us the image of a spiritually amputated community, the concrete solutions are given by Church programs, by counseling programs, and religious and humanistic psychotherapy. ${ }^{14}$

\section{CONCLUSION}

Today, we notice a change in our paradigm of culture and civilization, after switching to written culture, after the emergence of the typography and of the Internet, the use of the new technical means of social communication has radically changed our way of perceiving the world, our neighbors, God and civilization.

Fruit of human intelligence, the mass media have the duty to emphasize the communitarian spirit, the solidarity between people, the law and love, thus directly contributing to the creation of a society, which are still more human and closer to the wishes of people.

Apart from the information popularizing of public interest, the mass media is also responsible for the spread of the authentic culture, of the splendor of the truth ${ }^{15}$, of the perennial values of humanity, which have not only informative but also formative purpose. The end of the cultural act consists in a deeper "humanization" of man.

Going into the depths of his being, man inevitably discovers God, in the very depths of his soul, lying at the foundations of civilization and human culture itself ${ }^{16}$. The active commitment to serve the man, his education, turns the media into a main instrument with whose aid the cultural model of the 21-st century operates.

Nothing ever had a greater influence on our society, as the media today. Serving the truth, communications indirectly serve that "unknown God" (Acts 17:23), the God of whom the Apostle Paul spoke in the Athenian Areopagus. That is why every person engaged in the

\footnotetext{
${ }^{13}$ Encyclical Letter Evangelium Vitae, 96. (Personal translation)

${ }^{14}$ Alvin TOFFLER, Şocul viitorului (Future Shock), transl. into Romanian by Silviu Brucan, Politică, Bucureşti, 1973, p. 56.

${ }^{15}$ IOAN PAUL al II-lea (JoHn PAUL the second), Veritatis Splendor, 1, in: IOAN PAUL al II-lea, Enciclice, Editura Arhiepiscopiei Romano-Catolice de Bucuresti, Bucureşti, 2008, p. 497.

${ }^{16}$ I. MĂRTINCÃ, Cultura şi educaţia în Doctrina Socialã a Bisericii (Culture and Education in the Social Doctrine of the Church), Universitatea din Bucureşti, 2004, p. 243. V. https://ziarullumina.ro/actualitatereligioasa/regionale/banat/internetul-un-nou-mijloc-de-pastoratie-109728.html
} 
field of communications that serve the truth, serve deeply our humanity and the Creator at the same time ${ }^{17}$.

If the printing press, the radio and the television, by their specific language, proclaim truths congruent to the Great Truth, inform and educate, yet we cannot fail to notice a certain alienation that this illusion of false communion creates, only on the basis of information. The human community is based on direct, unmediated, personal dialogue, so anything else cannot take the place of true communion. ${ }^{18}$

It is neither better nor worse than the previous ones, but it is certainly something different, which is why we do not have to categorize hierarchically or criticize the written culture in relation to the virtual one, but only consider that our young people relate differently to the word.

That the youngsters read more or less is relative, not even the old generations were too much fond with lecturing; on the contrary, now they read more, even messages, or postings on Facebook or online newspapers, or articles of all kinds.

This important virtual space is the new mission field of the Church, not just a tactical field for services, or a marketing space for companies; it is a space in which we must be present and proclaim the word, we must be ready to support the christening or rechristening of both the new generations and the old ones.

Social networks can contribute to a better mutual understanding of different traditions and to the consolidation of faith communities ${ }^{19}$, as a space for new manifestation of the word; they also represent a new missionary space, the 'new Areopagus of our time', in which we must be, unmistakably, the new missionaries, who can bring peace and liberation ${ }^{20}$.

\section{BIBLIOGRAPHY:}

[1] Virgil Nemoianu, Jocurile divinităţii. Gândire, libertate şi religie la sfârşit de mileniu (The games of Divinity. Thought, Freedom and Religion at the end of the millennium), Polirom, Iaşi, 2000

[2] Etica în Internet. Biserica si Internetul (Ethics in the Internet. The Church and the Internet), Consiliul Pontifical pentru Comunicații Sociale Ercis, Iași, 2002

[3] Pr. Prof. Ion Bria, „Despre revelaţia dumnezeiască” (On the divine revelation), in: Glasul Bisericii, Year XXII (1964), no. 3-4,

[4] Giovanni Sartori, Homo videns. Imbecilizarea prin televiziune şi post-gândirea (Homo videns. Idiotizing through television and post-reasoning), transl. into Romanian by Mihai Elin, Bucureşti, Humanitas, 2005

[5] Christos Yannaras, Abecedar al credinţei (Elements of Faith: An Introduction to Orthodox Theology), transl. in Romanian by Rev. Dr. Constantin Coman, Bizantină, Bucuresti, 1996

[6] Le Culte de l'Internet. Une menace pour le lien social?, La Découverte, Paris, 1999,

[7] J.-Cl. MONOD, Écrire à l'heure du tout message, Flammarion, Paris, 2015

[8] Paul Evdochimov, Ortodoxia (The Orthodoxy), transl. into Romanian by Irineu Ioan Popa, Institutul Biblic si de Misiune al Bisericii Ortodoxe Române, Bucureşti 1996,

[9] St. Gregory of Nyssa, Despre suflet şi înviere (About the soul and resurrection), in: PSB, vol. 30, Institutul Biblic si de Misiune al Bisericii Ortodoxe Române, Bucureşti 1998,

17 https://ziarullumina.ro/actualitate-religioasa/regionale/banat/internetul-un-nou-mijloc-de-pastoratie109728.html

${ }^{18}$ Cf. Jean Claude LARCHET, Captivi in Internet, Sophia, Bucuresti, 2018, p. 54.

${ }^{19} \mathrm{https} / / /$ basilica.ro/patriarhul-daniel-despre-utilizarea-retelelor-de-socializare-si-a-internetului/

$20 \mathrm{https} / / / \mathrm{www} . v a t i c a n n e w s . v a / r o / p a p a / n e w s / 2019-01 / p a p a-f r a n c i s c-m e s a j-z i-m o n d i a l a-c o m u n i c a t i i-$ sociale.html 
[10]Ioan Paul al II-lea (John Paul the second), Internetul: un nou forum pentru proclamarea Evangheliei. Mesaj cu ocazia celei de a XXXVI-a Zi Mondială a Comunicaţiilor Sociale (The Internet: a new forum for proclaiming the Gospel. Message on the occasion of the XXXVI-th World Social Communications Day, 12 May 2002, Presa Bună, Iaşi, 2002,

[11]Benedict XVI, Mesajul pentru a 45-a Zi Mondială a Comunicațiilor Sociale (The message for the 45th World Day of Social Communications), 2011.

[12]V.: https://ziarullumina.ro/repere-si-idei/internetul-intre-comunicare-si-izolare-15816.html Encyclical Letter Evangelium Vitae, 96. (Personal translation)

[13]Alvin Toffler, Şocul viitorului (Future Shock), transl. into Romanian by Silviu Brucan, Politică, Bucureşti, 1973

[14]Ioan Paul al II-lea (John Paul the second), Veritatis Splendor, 1, in: IOAN PAUL al II-lea, Enciclice, Editura Arhiepiscopiei Romano-Catolice de Bucuresti, Bucureşti, 2008,

[15]I. mărtincã, Cultura şi educaţia în Doctrina Socialã a Bisericii (Culture and Education in the Social Doctrine of the Church), Universitatea din Bucureşti, 2004, https://ziarullumina.ro/actualitatereligioasa/regionale/banat/internetul-un-nou-mijloc-de-pastoratie-109728.html

[16] https://ziarullumina.ro/actualitate-religioasa/regionale/banat/internetul-un-nou-mijloc-de-pastoratie109728.html

[17]Cf. Jean Claude Larchet, Captivi in Internet, Sophia, Bucuresti, 2018,

[18] https://basilica.ro/patriarhul-daniel-despre-utilizarea-retelelor-de-socializare-si-a-internetului/

[19] https://www.vaticannews.va/ro/papa/news/2019-01/papa-francisc-mesaj-zi-mondiala-comunicatiisociale.html 